\title{
Central Asian Factors in Energy Relationship between China and Russia
}

\author{
Xiaoqin $\mathrm{Chen}^{1}$ \\ ${ }^{1}$ School of International Studies, Renmin University of China, Beijing, China \\ Correspondence: Xiaoqin Chen, Associate Professor, PhD of Law, School of International Studies, Renmin \\ University of China, Beijing, China. E-mail: cxqjwh@hotmail.com
}

Received: December 2, $2011 \quad$ Accepted: March 29, $2012 \quad$ Published: June 1, 2012

doi:10.5539/ass.v8n7p33

URL: http://dx.doi.org/10.5539/ass.v8n7p33

Supported by the Fundamental Research Funds for the Central Universities, and the Research Funds of Renmin University of China, 10XNJ051.

\begin{abstract}
After the disintegration of the Soviet Union, central Asian countries that acquired independence received high attention from great powers inside and outside the region in terms of their important geostrategic position, abundant energy and resource reserves and diversified and heterogeneous cultural patterns. Cooperation relationship of energy is an important component in foreign relations of central Asian countries. Being the major two neighboring nations of central Asian countries, China and Russia attach great importance to commercial interests, national security and geopolitical concern of central Asian countries and depend on each other in terms of preventing other great powers from intervening in central Asian affairs and maintaining regional security and stability. Central Asian region is the indispensable geostrategic space in development of China and Russia in the future, and mutual competition and negative influences caused thereby are inevitable, but this has also created opportunities for the two nations to go further into more extensive and profound cooperation. As regional cooperation and security schema, establishment of Shanghai Cooperation Organization (SCO) reflects the common interests of China and Russia in maintaining security of the Eurasia, which, simultaneously, has become a positive platform to coordinate energy relationship of the two countries in the central Asian region and to strengthen their cooperation.
\end{abstract}

Keywords: energy relationship between China and Russia, central Asian factors, energy interests, Shanghai Cooperation Organization (SCO)

With disintegration of Soviet Union in the 90s of the Twentieth Century, great changes have taken place in the geopolitical situation of the entire central Asian region. Central Asian countries have received high attention from great powers inside and outside the region in terms of their important geostrategic position, abundant energy and resource reserves and diversified and heterogeneous cultural patterns. Cooperation relationship of energy is an important component in foreign relations of central Asian countries.

China is one of the countries that have earlier comprehensive bilateral and multilateral cooperation with central Asian countries. Especially in the past several years when economy of China has been rapidly developed and China's dependency on foreign countries in terms of energy has been on the increase year by year, it has become a realistic and feasible strategic choice to maintain energy safety in China to increase import of energy from neighboring central Asian countries. Since the resource endowment, development capacity and actual distribution of the five central Asian countries are totally different, focus of China on energy cooperation within this region in terms of cooperation targets and fields is mainly on oil gas cooperation with Kazakhstan and Turkmenistan as well as cooperation with Kazakhstan in terms of atomic energy (since 2005).

As for Russia which has, all the time, regarded the central Asian region as a traditional sphere of influence, considering consistency of strategic interests of China and Russia and out of the strategic consideration to check and balance US and Europe so as to maintain balance of all external powers, it has actually acquiesced in penetration of Chinese capital in the central Asian region in the past few years. Nevertheless, mutual competition between China and Russia still exists within this region. Furthermore, this competition might be aggravated with 
Russia thoroughly initiating its modernization progress. Currently, economic modernization has been placed to the political agenda of Russian government which has determined its strategy for industrial innovative development and which proposed that they would change their dependence on energy and raw materials by the year 2020 and transfer to an innovative development mode. Furthermore, the Russian government planned to build "modernization alliance" within the global sphere and attempted to resort to external power to fulfill Russia's economic modernization. To this end, Russia has to make large-scale transformation and renovation on domestic infrastructure, which will necessarily increase largely its energy import from central Asian countries. Simultaneously, Russia vigorously motivates regional economic integration with the Commonwealth of the Independent States to enable them to become strategic backbone for Russia to revitalize its status as a big power (Громов А.И., 32-33).

Thus, it can be found that, the geopolitical and economic interests of China and Russia are overlapped inevitably in the central Asian region, which will necessarily affect energy cooperation of the two countries within the region, namely, whether cooperation partners or competitors? From the perspective of Russia, this, to great extent, is determined by whether these two countries can establish a long-term, multilateral, stable and mutually beneficial economic and trade relationship within the two important integration organizations in this region --Eurasian Economic Community (EURASEC) and Shanghai Cooperation Organization (SCO). In order to more clearly expound under what background China and Russia can become energy cooperation partners within this region or, on the contrary, these two countries compete in terms of energy for respective comparative advantages, this article analyzes with emphasis energy interests of the two countries within the central Asian region and how Russia looks upon its energy cooperation with China and the central Asian countries as well as what kind of opportunities and challenges will be encountered in development of energy relationship between China and Russia.

\section{Game Playing of China and Russia in the Central Asian Region in Terms of Energy Interests}

The first twenty years of the Twentieth Century is deemed as the "period of strategic opportunities" in peaceful development of China and also as a critical period to realize industrialization and urbanization, during which dependency of economic and social development on foreign energy resources continued to increase. Out of consideration of sustainable development of the economy, the primary task of China in conducting international energy cooperation is to establish a diversified, stable and reliable energy supply system and to strengthen cooperation in oil and gas with major areas and countries in the world which are abundant in oil and gas, while deepening cooperation with Russia and neighboring central Asian countries in terms of energy exploration and pipeline transport and striving for long-term and stable supply of oil and gas from onshore neighboring countries is a critical aspect for China to carry out the diversification strategy in importing of energy and resolve the "Malacca Predicament".

The central Asian region is one of the regions in the world that have abundant reserves of oil and gas and has become the "potential stock" in world energy exploration in the $21^{\text {st }}$ Century that is characterized by large explored reserves and small yield. Considering the economic developmental history of the five countries of the central Asian region, the energy industry of oil and gas is the backbone of its economic development. From the perspective of trade complementarity, what China imports mostly from the central Asian countries is raw material that is in sufficiency in China, which, in essence, is determined by the natural resource conditions, industrial structure and economic development stage of countries involved and which also complies with the strategic thought of the central Asian countries to attract foreign investment with resources to drive their economic development.

From the perspective of capital, with long-term accumulation of rapid development and foreign exchange reserves of China for three decades, Chinese capital is positively flowing into economy of central Asian countries. Especially since the outbreak of the international financial crisis in 2008, both the financial system and substantial economy of Russia and central Asian countries have suffered from massive attack. Furthermore, owing to correct train of thought and appropriate measures in reacting to the crisis, China not only takes the lead in walking out of the crisis, but also has a foreign exchange reserve as high as over 2 trillion US dollars and jumps to be the top in the world. Under the circumstance when western countries and Russia keep a greatly shrunk investment in economy of central Asian countries, China taps its capital superiority and applies the mode of "oil for loan" into its cooperation with central Asian countries in terms of energy. In April 2009, China and Kazakhstan signed the loan assistance agreement that China offered a loan worthy of 10 billion US dollars to Kazakhstan; in June of the same year, China and Turkmenistan signed a loan agreement that China offered a loan worthy of 4 billion US dollars to Turkmenistan. Currently, central Asian countries not only regard China as a major trade partner, but more an important strategic investing country since the loan offered by China not only 
helps central Asian countries to maintain and enlarge development of oil resources, but also creates favorable conditions for central Asian countries to have long-term and stable supply of oil and gas to China, complying with common interests of both of the parties involved.

Energy interests of China in the central Asian region are listed as follows. Firstly, the central Asian region is located in the central area of Eurasia, neighboring to the western China and abundant in resources, so it is an important strategic target cooperation region for China to realize stable development of western China and conduct foreign energy cooperation. Secondly, the three countries of Kazakhstan, Turkmenistan and Uzbekistan are affluent in oil and gas reserves and are expected to become potential countries that supply oil and gas to China. Thirdly, uranium ore reserves of Kazakhstan and Uzbekistan are quite considerable, and there is enormous potential for them to have cooperation with China in terms of nuclear energy. Fourthly, the status of transit transport of central Asian region is quite significant, and the Eurasia traffic and transportation network that is under construction is of great significance to maintain Chinese energy transportation safety. Fifthly, Kyrgyzstan and Tajikistan are extremely abundant in hydroenergy resources, yet with low utilization rate, and are one of the regions for China to select in its hydroelectric cooperation in the future. So far as the current stage is concerned, the key field for energy cooperation between China and central Asian countries is exploration, development and utilization of oil, gas and uranium ore resources.

Oil that is imported by China from the central Asian region mainly comes from Kazakhstan, and it occupies the top within this region in both reserves and yield of crude oil that has been explored, with enormous potential of export of oil. In 2009, the import volume of crude oil in China broke through 0.2 billion tons for the first time and achieved 0.203 billion tons, exceeding Japan to become the second largest importing country of crude oil in the world. It has been a foregone conclusion that its dependency on foreign countries in terms of crude oil surpasses $50 \%$, which is predicted to increase to $65 \%$ by the year 2020 . Thus, the task is quite urgent to realize diversification of energy supply. At present, China is able to import a volume of 10 to 20 million tons of crude oil from Kazakhstan each year through the Sino-Kazakhstan oil pipeline, which approximately accounts for $10 \%$ of the total importing volume of crude oil. Ever since the financial crisis, China and Kazakhstan have achieved new progress in exploration of oil and gas. In 2008, China-invested enterprises led by CNPC (China National Petroleum Corporation) exploited 15 million tons of crude oil (approximately $21 \%$ of the total crude oil exploited in Kazakhstan within the same year) within the border of Kazakhstan. Which was almost 2.5 times of the total exploitation volume by Russian enterprises. After having successfully acquired part of oil and gas assets of Kazakhstan, China-invested enterprises exploited as much as 18 million tons of crude oil within the border of Kazakhstan in 2009, which occupied 23\% of the total crude oil exploited within the border of Kazakhstan.

In the aspect of natural gas resources, Turkmenistan is not only abundant in reserves, but also has a considerable potential in export, the most important exporting country of natural gas within this region. The natural gas that is produced by Kazakhstan and Uzbekistan is mainly used for domestic consumption, since their capacity of exporting is limited. In December 2009, Sino-Central Asian gas pipeline was put into operation. According to the gas agreement between Turkmenistan and China, Turkmenistan will export a volume of 40 billion cubic meters of gas to China through this pipeline in the 30 years afterwards, whereas China will offer a loan of 4 billion US dollars with a preferential interest rate to Turkmenistan. The whole-line connection of Sino-Central Asian gas pipeline symbolizes that the diversification strategy of host countries of resources in the central Asian region in terms of energy exportation has attained significant progress and excessive dependency on Russian gas pipeline has been reduced (Ся Ишань, 46-49). However, it is obvious that this does not comply with the entire interests of Russia that is represented by the energy giant "Russian Gas" since Russia has ever been the monopoly importing country and transit transporting country for gas of Turkmenistan to be exported to foreign countries.

Although energy cooperation between China and the central Asian region has always been led by oil and gas, the tendency of diversification has been gradually manifested in the past several years, which is characterized by nuclear energy cooperation with Kazakhstan, cooperation with Kazakhstan, Uzbekistan, Tajikistan and Kyrgyzstan in terms of power station and power grid construction and cooperation with Kyrgyzstan in the field of coal.

Being the major two neighboring nations of central Asian countries, China and Russia attach great importance to commercial interests, national security and geopolitical concern of central Asian countries and depend on each other in terms of preventing other great powers from intervening in central Asian affairs and maintaining regional security and stability. Nevertheless, the two countries have diverged interests in controlling the energy resources and oil and gas pipelines of this region. For instance, as an energy importing country, China is dedicated to realize diversification in importing of energy in order to ensure acquisition of stable energy supply, whereas as an energy production country and transit transporting country, Russia attempts to control energy 
output channels from the upstream so as to exert more influences upon other energy consuming countries. In the long run, the central Asian region is the indispensable geostrategic space in development of China and Russia in the future, and mutual competition and negative influences caused thereby are inevitable, but from another perspective, this has also created opportunities for the two nations to go further into more extensive and profound cooperation.

For the past few years, with stable progressing of the diversification strategy in China's importing of energy in the central Asian region, Russia has felt worried about China's dispersing its economic interests, and especially its energy resources in the central Asian region, believing that the swift penetration of Chinese influence might bring about the following several negative outcomes to development of Russia and the central Asian region in the future (Парамонов В.В., Строков А.В. \& Столповский О.А., 77):

In the first place, capacity of control of Russia on central Asian energy and other raw materials will be weakened to some extent. In the long run, this might damage the energy interests of Russia. If we say that Russian energy industry is seldom affected by situation of central Asian resources in the oil, hydroelectric and coal fields, then the natural gas and uranium ore of the central Asian region are resources that have decisive effects upon economy of Russia. Especially at a stage when domestic electric reform of Russia has entered a crucial period, Russian government formulates a plan for comprehensive development of generation of electricity and power grid infrastructure to, on one hand, ensure natural gas supply for power stations that are under construction, and, on the other hand, realize diversification of energy production and consumption structure. In addition, Russian government has established a series of indexes to be attained prior to the year 2030, among which the proportion of nuclear power in electric production structure of Russia will rise from the current $15.8 \%$ to $23 \%-25 \%$ (Язев B.A., 4).

By this token, a competitive relationship is constituted between China and Russia in terms of orientation of energy in the central Asian region. As for China's oil activities in the central Asian region, Russia fully manifests its important status as an energy transit transporting country. On May 12, 2007, the heads of Russia, Kazakhstan and Turkmenistan and the president of Uzbekistan made a joint statement that they would update and innovate the current natural gas pipeline that run from the central Asian region to Russia and lay a new Caspian pipeline. On December 20 in the same year, Russia, Kazakhstan and Turkmenistan formally signed " Caspian Coastal Gas Pipeline Agreement" in Moscow, predicting that the newly constructed pipeline from Turkmenistan and Kazakhstan to Russia would be connected with the former pipeline, and designing an annual delivery capacity of 20 billion cubic meters. Once the Caspian natural gas pipeline project is put into effect, a natural gas delivery system with the largest scope will be formed in the central Asian region, which may further strengthen Russia's dominant rights to outbound freight of central Asian energy. Besides, progress of China and Kazakhstan and Uzbekistan in exploration and development of uranium ore in the past few years also has aroused high attention of Russia.

In the second place, in view of continuously deepened energy cooperation between China and central Asian countries in terms of both scope and extent, this might make the external competitive environment of the central Asian countries in the field of energy more complicated. That is to say, positive participation of Chinese energy enterprises may intensify struggle of foreign companies including East Asian and western countries for central Asian resources. According to Russian government, excessive competition may necessarily break down the strategic balance between different regions in the Eurasia and stimulate central Asian countries to pursue a policy that makes them go far gradually away from Russia, which may not only cause Russia's efforts to realize integration of energy and even economy within this region to be wasted, but also may speed up the trend of regional polarization of the entire post-Soviet.

In the third place, for the time being, the trade structure of "finished products for resource products" that is formed between China and Russia and central Asian countries is not helpful for actual establishment of the strategic collaboration relationship of China and Russia, but, instead, has enlarged possibility of the interest conflicts of the two countries. The overall characteristics of industrial structure $f$ central Asian countries is resource intensive. Compared with rapid development of China economy, the social and economic development of central Asian countries is relatively low and the phenomenon of deficiency in capital generally exists. This actual condition makes quite a lot of large-scale cooperation projects within this region dependent on investment of China, as a result of which may not only make it difficult to form a developmental situation of win-win of multiple parties, but also does not comply with long-term interests of China. Just considering China's acquisition of energy supply from this region, in no way, will the serious unbalancedness of economic development can ensure that the central Asian region will have a secure and stable investment environment. Hence, both Russia and central Asian countries wish that China could make a difference in the field of regional economic 
cooperation, push forward more balanced import and export trade and bilateral investment, enhance the overall competitive force of this region in the global economy and strengthen the common interests of China and Russia in maintaining security of the central Asian region.

\section{Discussion on Cooperation Means and Approaches of China and Russia}

Although China and Russia have large discrepancies in energy interests within the central Asian region and the strategic targets they pursue are thoroughly different, there is objective consistency in terms of their long-term interests in the central Asian countries, namely, facilitating healthy social and economic development of the region at the same time of maintaining strategic stability of Eurasia. As for China and Russia, after the "9.11" Incident, US intended to resort to its long-term military presence in the central Asian region to constrain the two countries from the perspective of geostrategic perspective, which also becomes a great concern of China and Russia in their security in surrounding regions and in their overall strategic interests.

For a long time, Russia has mistakenly believed that it owns more powerful regional influence in the central Asian region than other great powers, and it has propelled the Collective Security Treaty Organization that is totally under its control to become a major safety mechanism in the central Asian region and has attempted to resort to such international mechanisms as the Commonwealth of the Independent States and Eurasian Economic Community (EURASEC) which do not contain China to push forward regional economic integration progress. However, ever since the "9.11" Incident, US has established its strategic superiority in the central Asian region where it has been seldom involved, whereas Russia's strength in this region has been far less than that at the Soviet era. Thus, Russia' attitude in the recent years in strengthening cooperation between China and Russia within the framework of the Shanghai Cooperation Organization (SCO) has been towards active, since what SCO differs from regional organizations that are led by Russia, such as, Collective Security Treaty Organization, is that SCO balances the interests of two great powers within a region. Only if China and Russia negotiates together to resolve the topic of the central Asian region within the framework of SCO, can the two countries have sufficient ability to resist US influences upon the central Asian region, which is unable to be realized merely with effort of either of the two.

As regional cooperation and safety framework, SCO has another obvious characteristics that it enables central Asian countries to seek for approaches to promote cooperation and safety with great powers within the region on an equal basis. Hence, central Asian countries are with great pleasure to participate in SCO to take actual measures to realize regional security and economic development, such as, establishment of trust, anti-terrorist, fighting against drug trafficking, safeguarding border security, economic and trade cooperation and investment, improvement of traffic facilities, energy development and utilization and so on. Within the SCO framework, although the space for maneuver of the four member countries (Kazakhstan, Uzbekistan, Kyrgyzstan \& Tajikistan) of the central Asian region is inferior to that of the two great neighboring countries of China and Russia, their strategic targets have similarities with those of China and Russia: China and Russia resort to SCO to check and balance US hegemony, whereas the four member countries resort to SCO to ensure mutual check and balance of all external powers. Since China is regarded as a power to check and balance US and Russia, entry of China into the central Asian region can help these inland countries to lay new oil and gas pipelines and offer new energy export directions. Thus, it is generally expected by the central Asian countries to strengthen energy cooperation within the framework of SCO.

Development of SCO is the epitome of political transformation of great powers in the central Asian region. In the past few years, China has been enthusiastic in taking part in relevant activities of SCO, and, simultaneously, held powerful bilateral diplomacy with central Asian countries, continuously enhancing its influential strength within this region by means of trade and investment, etc. As a former superpower, currently, Russia plays more a role of a regional big power. In face of China's increasing influences and active actions in the central Asian region, Russia begins to practically believe that SCO can become a "legal platform for Russia to strive for interests, assume heavy burdens, resolve common concerns and strive for international social support” (Лукин А.В., 15). At the level of strategy, Russia's primary concern is that SCO can play its role as a safety organization and only play its limited economic role in common infrastructure projects. By contrast, China's primary concern is that $\mathrm{SCO}$ is able to make a difference in pushing forward regional economic integration with higher degree and constructing unified energy space. Out of such consideration, Russia is quite sensitive to China's proposal to set up free trade zones, with the concern that free flow of commodities, capital and personnel might cause China's "economic expansion" in Russia and the central Asian countries and affect functioning of the EURASEC dominated by Russia and its control over energy resources development and export pipeline network in the central Asian region. 
China and Russia are both crucial participants of central Asian affairs, and although these two countries have diverse opinions in the central Asian issues, they have come gradually to consensus in the view that both of the two can be injured in competition. Competition in the central Asian region is not in line with interests of China and Russia whether in terms of politics or in terms of strategy since competition might cause various destructive factors within the region (terrorism, drug trafficking and so on) to take advantage of the competition. As a matter of fact, what China and Russia are in urgent need is to cooperate in the central Asian region, especially in the field of energy, for energy has become a field which is most rapid for mutual collaboration and development in a globalization era when demand of energy is on a daily increase. Gaming or struggle for energy in the central Asian region is "a game with no winner" since it will not bring permanent interests to any party involved. On the contrary, it is a reliable approach for Russia and central Asian countries to realize industrial innovation development to make effective use of potentials of all sorts of energy, make an overall planning of a regional economic integration blueprint, avoid unordered competition, share all sorts of resources in politics, economy, military and energy, and resist foreign pressure together.

From the above analysis, it can be found that establishment of SCO has not only reflected common interests of China and Russia in maintaining security of the central Asian region, but can also become a perfect platform to coordinate energy relationship of the two countries within this region and to strengthen their cooperation. Obvious is the complementarity of advantages of all member states of SCO in terms of energy resources, energy market and energy transportation. For the time being, the most stringent task for energy cooperation within the organization is to set up a cooperation mechanism that is able to take into account balance of interests of producing countries, exporting countries and transit transporting countries, determine a number of cooperation projects that are most urgently required by member states and that are most likely to bring substantial interests for member states and create a win-win pattern for all member states.

From the perspective of Russia, in order to promote regional economic integration together with China, at the primary stage, Russia ought to make full use of the transit potential of member states, strengthen the role of the central Asian region as a bridge across Europe and Asia and form unified transportation space and cross border traffic and transportation network, so as to lay foundations for maintaining internal strategic stability, economic balance and sustainable development of Eurasia (Парамонов В.В., Строков А.В., \& Столповский О.А., 78). Currently, to push forward construction of international transportation corridor in the central Asian region and within the framework of SCO is one of the directions for efforts of Russia, indicating that at the time when Russia wishes to consolidate its own status in transit transportation, it is reluctant that China alone acquires resources within the central Asian region, so it attempts to maintain the strategic intention of regional balance.

Standing on the viewpoint of China, actually another important measure to strengthen China's energy security is to open a transportation channel that is directly through to Europe in addition to the primary choice for diversification strategy in energy export in China to increase export of energy from Russia and central Asian countries, namely, to re-construct "the new energy silk road" and gradually generate a comprehensive cooperation system which covers the entire chain of energy industry. Meanwhile, it helps central Asian countries to expand approaches for export of energy. This measure will vigorously facilitate regional economic integration and economic revival of this region, which can be said to achieve several achievements at one stroke and benefit multiple parties involved.

Hence, it can be seen that, the vision of China to get through the "new energy silk road" is, to some extent, similar with the plan of Russia and central Asian countries to build "Eurasia Land Bridge". China's vision can become a powerful bond to link together the development interests and security interests of all countries. Hence, this vision will be a key direction for energy cooperation between China and Russia and central Asian countries within a certain period in the future. In the recent several years, China has enlarged its vigor of investment in central Asian traffic and transportation infrastructure construction and a number of demonstrative projects have been put into effect in succession in which several parties participate and which all parties benefit from, including use and dilatation of existing energy facilities and pipelines (oil and gas pipelines and power transmission network) and modernization reformation on railways and highways. Establishment of central Asian traffic and transportation network can not only maintain interests of the parties involved, but also has taken into consideration the concerns of Russia and brought tangible and visible benefits to Russia, helpful to direct Russia to come to understand and approve the new type of energy safety concept that is proposed by China and that is centered with "mutual beneficial cooperation, diverse development and coordinated guarantee", which, altogether, creates conditions for harmonious development of energy relationship between China and Russia and for the two countries to add to trust and resolve doubts and fulfill common energy security.

As the leading forces for stability and development of Eurasia, China and Russia focus more on long term 
interests, but neither of the two countries is able to finish the task to establish large-scale cooperation in the central Asian region and surrounding regions. Thus, establishment a win-win idea that complies with the tide of the times and the local reality and encourage central Asian factors to play a more active and constructive role in energy relationship between China and Russia is the footstone and guarantee to overcome difficulties and impediments that still exist in the current Sino-Russian energy cooperation and to set up a new type of energy cooperation platform.

\section{References}

Громов А.И. (2010). Энергетическая стратегия России - 2030 и ее восточный вектор // Энергетическая политика, (4-5).

Лукин А.В. (2007). Шанхайская организация сотрудничества: что дальше?// Россия в глобальной политике, (3).

Парамонов В.В., Строков А.В., \& Столповский О.А. (2010). Центральная азия в энергетической стратегии Китая. Последствия и возможности для России // Энергетическая политика, (4-5).

Ся Ишань. (2010). Энергетическая стратегия Китая в новой ситуации и энергетическое сотрудничество Китая и России // Энергетическая политика, (4-5).

Язев В.А. (2007). Вступительное слово на парламентских слушаниях на тему: "О законодательном обеспечении оптимизации топливно - энергетического баланса Российской Федерации" // Энергетическая политика, (2). 